Marquette University

e-Publications@Marquette

$1-1-2013$

\title{
Older Workers, Occupational Stress and Safety
}

Gary A. Adams

Marquette University, gary.adams@marquette.edu

Sarah DeArmond

University of Wisconsin - Oshkosh

Steve M. Jex

University of Wisconsin - Oshkosh

Jennica R. Webster

Marquette University, jennica.webster@marquette.edu

Published version. "Older Workers, Occupational Stress and Safety," in SAGE Handbook of Aging, Work and Society. Eds. Ronald J. Burke, Cary L. Cooper, and John Field. London: SAGE Publications, 2013: 266-282. Publisher link. (C) 2013 SAGE Publications. Used with permission. 


\title{
Older Workers, Occupational Stress and Safety
}

\author{
Gary A. Adams, Sarah DeArmond, \\ Steve M. Jex and Jennica R. Webster
}

\section{OLDER WORKERS OCCUPATIONAL STRESS AND SAFETY}

A series of well-established demographic trends such as increased life expectancies and changing patterns of birthrates are bringing about an aging of the world's population (Kinsella \& He, 2009). One of the key issues stemming from population aging is the aging of the workforce and older people's continued participation in paid work. Continued workforce participation among aging workers is currently being encouraged by a number of forces including social concerns, the needs of employing organizations and older workers themselves. At a societal level retaining older people in the workforce is at least partially driven by economic concerns about the viability of old age social insurance programs (e.g.. The Economist, 2011). At an organizational level, employers are interested in retaining older workers as a means to avoid potential skills shortages and the loss of organizational specific knowledge that can occur when oider workers leave the workforce (Burke \& Ng, 2006: DeLong, 2004; Manpower Group, 2011). Older workers themselves express interest in continued work owing to financial concerns as well as the desire to remain active, maintain social relationships and other nonfinancial returns from work (Dendinger, Adams, \& Jacobson, 2005; Loi \& Shultz, 2007). The combined effect of these trends is an increasingly older workforce.

The aging of the workforce brings with it a number of issues which are explored among the various chapters that comprise this Handbook. Among these issues are the topics of occupational stress and safety. Despite the fact that the workplace has become safer in many regards and that, in general, continued work is associated with better physical and mental health (Yeomans, 2011); the workplace can still be hazardous to one's health (International Labour Organization, 2011). These hazards stem from (1) occupational stress issues arising mainly from the psychosocial work environment and (2) safety 
issues arising mainly from accident/injuries (Wegman \& McGee, 2004). Although difficult to quantify, occupational stress hazards (often referred to as stressors) have been shown to be related to various indicators of poor mental and physical health, absenteeism, healthcare utilization and decreased productivity (European Agency for Safety and Health at Work, 2009; International Labour Organization, 2011; Jex \& Crossley, 2005; Leka \& Jain, 2010). With regard to accidents/injuries, in the US alone, the Centers for Disease Control and Prevention (2011) reported that there were more than 1.2 million non-fatal work-related injuries and illness resulting in time away from work in 2009 and approximately $17 \%$ of these were workers over the age of 55 . The CDC (2011) also reported 4,551 fatal workplace injuries in 2009 . Of these, approximately $31 \%$ were among those over the age of 55. Clearly, occupational stress and safety are important concerns for all workers. They are especially important for aging workers because of the increasing number of older workers, because they limit workforce participation, and because the aging process itself may be related to the nature, type, and consequences of occupational stress and safety.

The purpose of this chapter is to explore the role of chronological age in the areas of occupational stress and safety among older workers. We begin by briefly presenting a conceptual model identifying the possible relationships linking age to variables commonly studied in the area of occupational stress and safety. Then, we provide a review of representative research examining these linkages, incorporating relevant theory and highlighting the fact that the knowledge-base regarding these linkages is scant. We recognize that while there is some convergence between the two areas, research about occupational stress and safety grew out of two separate research traditions. Research on occupational stress has focused on the relationship between the psychosocial environment and wellbeing, whereas safety research has focused on accidents/injuries. Accordingly we divide the review along these two lines. We conclude with suggestions for future research.

\section{CONCEPTUAL MODEL LINKING AGE TO OCCUPATIONAL STRESS AND SAFETY}

Figure 15.1 presents a conceptual model linking age to concepts in the occupational stress and safety literatures. To begin, the model recognizes that chronological age is most often used as a proxy for more substantive age-related changes (most commonly losses) in physical and mental abilities that are thought to impair functioning at work as well as age-related changes (gains) in adaptive resources that allow older workers to maintain and even improve functioning at work (Salthouse \& Maurer, 1996; Warr, 1994). Next, it identifies the main antecedents and individual outcomes found in the occupational stress and safety literatures (Barlow \& Iverson, 2004; Kahn \& Byosiere, 1992, Sonnentag \& Frese, 2003). These antecedents include stressors as well as safety-related attitudes and behaviors of the workers. The negative outcomes include physical, psychological and behavioral outcomes as well as occupational injuries and accidents. Finally, the model shows three possible relationships between age (via age-related losses and gains), antecedents, and outcomes. The first possible relationship is a direct relationship between age and antecedents. The second is a direct relationship between age and outcomes. These direct relationships suggest that as people get older they are more or less likely to experience certain types or amounts of antecedents and outcomes. The third type of relationship age might have is a moderating effect. This means that the relationship between antecedents and outcomes is different for workers of different ages. More specifically, this could mean one of two things. First, age could attenuate relationships between some antecedents and outcomes; that is, increased age could be a protective factor. Secondly, age could strengthen relationships 


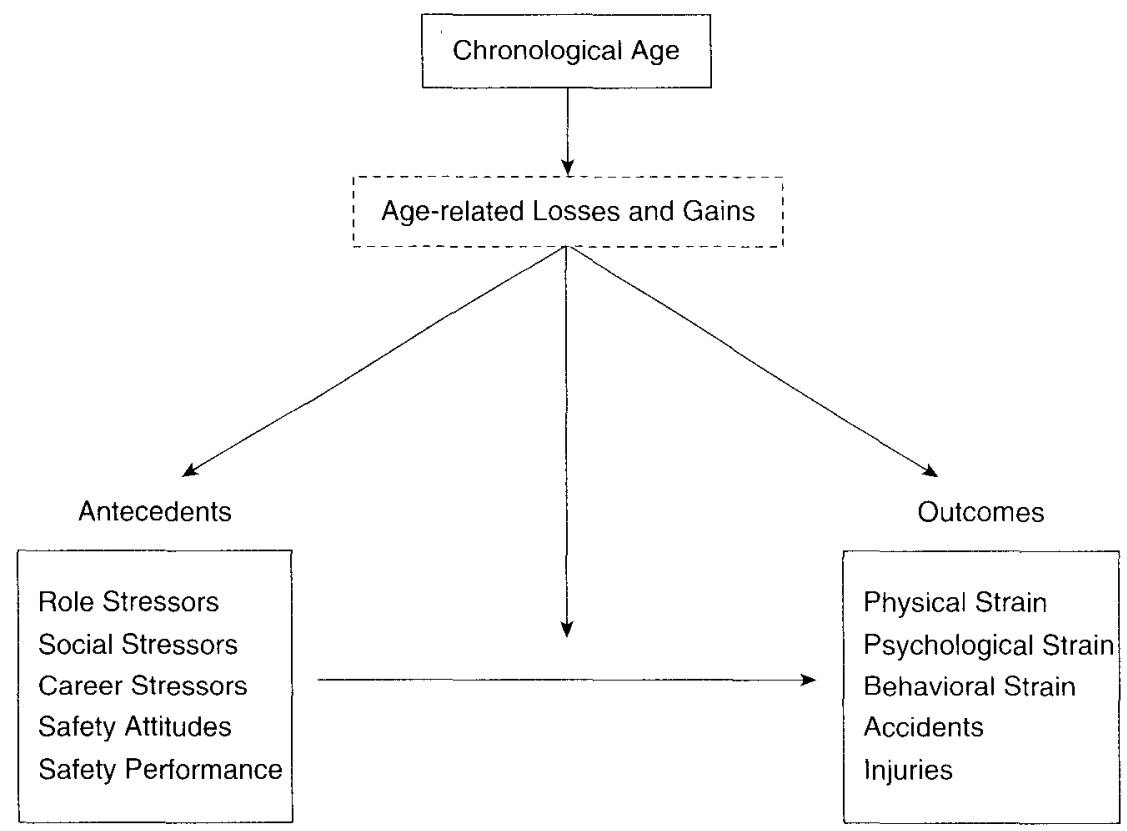

Figure 15.1 Conceptual model linking age to concepts in the occupational stress and safety literatures

between antecedents and outcomes; that is, increased age could be a vulnerability factor. In the sections that follow we review the theoretical and empirical arguments linking age to occupational stress and safety.

\section{AGE AND OCCUPATIONAL STRESS}

Within the occupational stress literature the term stressor is used to indicate characteristics of the work environment that prompt a negative reaction on the part of the worker experiencing it. The term strain refers to the negative reaction that comes as a result of a stressor (Jex \& Beehr, 1991). In terms of Figure 15.1, stressors are antecedents and strains are outcomes. In this section we begin by describing the relationships among age and stressors followed by age and strains.

\section{Age and stressors}

A great deal of research has examined stressors in the workplace (Kahn \& Byosiere, 1992).
Relatively few studies, however, have examined the relationship between age and workplace stressors. This is unfortunate because there are a number of good reasons to believe that age is directly related to the stressors older workers experience. A myriad of workplace stressors have been identified in the occupational stress literature (Sonnentag \& Frese, 2003). In this section we review theory and research on the relationship between age and a number of commonly identified stressors. These include: (1) role stressors, (2) social stressors, and (3) career-related stressors.

\section{Role stressors}

Role stressors, which consist of role ambiguity, role conflict, and role overload (Katz \& Kahn, 1978), are three widely studied stressors in the occupational stress literature. Role ambiguity exists when there is a lack of clarity about the prescribed roles of the job and role conflict occurs when there are incompatible role expectations. Role overload refers to situations when the expectations of the 
role cannot be met. Research tends to find negative relationships between age and both role ambiguity and role conflict (Jackson \& Schuler, 1985; Ng \& Feldman, 2010). This suggests that older workers report experiencing lower levels of these stressors than younger workers. There are two possible explanations for these findings. First, as workers age they accumulate more work experiences acquiring more occupational expertise and wisdom (Kaufman \& Lichtenberger, 2002; Schaie, 1996), which may act as a resource when dealing with role-related stressors. Second, older workers are more likely to be in high status positions with certain characteristics including job control, flexible work schedules, and access to support from the job environment. These job characteristics may reduce employee exposure to stressors such as role ambiguity and role conflict (Zacher \& Frese, 2009; Zacher, Heusner, Schmitz, Zwierzanska, \& Frese, 2010).

Role overload occurs when the physical and/or cognitive demands of the work role exceed the worker's capacity to fulfill them. There are two competing arguments on the possible relationship between age and overload. The first stems from the 'decrement' model of aging (Giniger, Dispenzieri, \& Eisenberg, 1983). It argues that the loss of physical and cognitive abilities associated with the aging process ultimately lead to poor functioning at work. Physical losses include decreased aerobic ability, physical strength and endurance, balance, manual dexterity and tolerance for heat (Maertens, Putter, Chen, Manfred, \& Huang, in press), which would seem to make it more likely that older workers would experience more physical overload compared to younger workers. For example, loss of muscle mass makes it more difficult to lift heavy objects; the loss of endurance reduces the ability to carry out tasks involving sustained or repetitive physical effort. Cognitive ability losses occur in the area of fluid intellectual abilities including processing speed, working memory, attention, and abstract reasoning (Park, 2000). Because of these age-related cognitive declines it may be more difficult for older adults to complete tasks that require the retention of large amounts of information or vigilant monitoring of the environment (Wang \& Chen, 2006). These would seem to make it more likely that older workers would experience more cognitive overload compared to younger workers.

A second perspective argues that older workers are better at managing their physical and cognitive resources and are therefore less likely to experience overload. The theory of selective optimization with compensation (SOC) is based on the assumption that people have a limited number of resources (physical and cognitive) and have to choose how to allocate those resources (Baltes, 1997; Baltes \& Baltes 1990; Freund \& Baltes, 2002). Selection refers to a strategy where people utilize their strengths by focusing on tasks (or jobs) on which they already perform well, for example, by transitioning into jobs that better match their abilities (Ackerman, Beier, \& Bowen, 2002; Warr, 1997). Optimization strategies include strengthening skills needed to complete tasks or putting more time/effort into completing a task. Compensation strategies refer to the use of external and internal aids to help overcome declining abilities. External aids such as new technologies including voice recognition software and larger font sizes can help older workers adapt to some of the age-related losses they experience (Charness, Czaja, \& Sharit, 2007). Older workers may also use 'internal' aids. For example, they may rely on crystallized intelligence including job expertise, job-related problem solving abilities, and a wide-range of life experiences to compensate for declines in fluid intelligence (Kanfer \& Ackerman, 2004). There is growing empirical evidence suggesting that SOC strategies can help older workers maintain job performance (Yeung \& Fung, 2009).

In summary, it appears that older workers may be at lower risk for experiencing role ambiguity and role conflict provided that they are able to leverage their acquired resources (e.g., expertise) and are in environments that 
provide them with control, flexibility and support. While there are competing arguments for the relationship between age and role overload there is too little empirical evidence to determine which of those arguments is most strongly supported. We suspect that, like role ambiguity and role conflict, the risk for role overload depends on the ability and opportunity older workers have to leverage their resources in order to offset their losses.

\section{Social stressors}

Social stressors consist of poor social interactions with people inside the organization (e.g., co-workers and supervisors) or outside the organization (e.g., customers; Sonnentag $\&$ Frese, 2003). Several types of social stressors have been identified in the work stress literature including bullying (e.g., Rayner, 1997), incivility (e.g., Andersson \& Pearson, 1999), interpersonal conflict (e.g., Spector \& Jex, 1998), and abusive supervision (e.g., Tepper, 2000). Although there are subtle differences among these types of social stressors they are similar in that they are forms of interpersonal mistreatment that target an individual (Hershcovis, 2011).

Although most workers are likely to experience social stressors in their work environment, not all workers will experience these stressors equally. Older adults, for example, are not as likely to report emotional distress due to social tensions compared to younger adults (Birditt \& Fingerman, 2003). This is consistent with socioemotional selectivity theory (SST), which argues that as people age they realize a shorter lifespan horizon and become more selective with how they invest their time and resources (Carstensen, Isaacowitz, \& Charles, 1999). More specifically, as people begin to perceive they have less time to live they focus their energy in meaningful relationships, and maximize the experience of positive emotions (Ready \& Robinson, 2008). For example, in order to gain positive emotions, older adults surround themselves with people with whom they have rewarding relationships. Because older adults tend to spend more time with these people it is less likely that they will be exposed to interpersonal mistreatment. In addition, in order to increase positive emotions, older adults develop emotional regulation strategies that filter negative information (Mather \& Carstensen, 2005). This type of emotional regulation strategy helps older adults to effectively manage interpersonal conflict situations (Birditt \& Fingerman, 2005). Some cvidence for this in a work setting comes from a study by Dahling and Perez (2010); they found that older workers express more positive affect and naturally felt emotions.

Older workers, however, are more likely to experience social stressors stemming from ageism compared to younger workers. Ageism is the systematic stereotyping of and discrimination against older people because they are old' (Butler, 1989, pp. 139). Age stereotypes are the beliefs and expectations people have about older workers that are often negative and inaccurate (Fiske \& Neuberg, 1990). Several different types of stereotypes about older workers have been noted in the literature including the belief that older workers are inflexible and unwilling (or not able) to adapt to change, less able to learn new skills, less productive, and more expensive compared to younger workers (Brooke \& Taylor, 2005; Kite \& Johnson, 1988). Negative stereotypes about older workers are widespread in organizations and are often assumed to be the cause of age discrimination albeit research shows only a modest relationship (Finkelstein \& Farrell, 2007; Shore \& Goldberg, 2004). Age discrimination exists when an employee is treated unfairly due to his/her age and is shown to be a major issue in US organizations. In 2010, the US Equal Employment Opportunity Commission (2011) received over 23,263 complaints of age discrimination. Empirical studies have shown that older workers receive more negative hiring, promotion, and performance appraisal evaluations (Gordon \& Arvey, 2004) compared to younger workers and harsher consequences for those poor performance 
ratings (e.g., transfer, request for resignation, demotion; Rupp, Vodanovich, \& Crede, 2006). Thus, while older workers are less likely to experience generalized mistreatment, they are more likely to experience mistreatment based on ageism.

\section{Career-related stressors}

Career-related stressors include those that can hinder or threaten the progression of one's career. Types of career-related stressors that are commonly studied in the organizational literature include job insecurity and skill obsolescence. Job insecurity occurs when workers feel threatened by potential job loss (Probst, 2004). Downsizing, mergers, and acquisitions have led to increased feelings of job insecurity for all workers, especially those who are older (Armstrong-Stassen \& Cattaneo, 2010). Skill obsolescence refers to the depreciation of knowledge or skills needed to effectively perform in a current or future work role. Older workers are especially vulnerable to skill obsolescence and job insecurity compared to younger workers owing to the negative effects of ageism. The evidence suggests that older workers are less likely to receive support for (Greller \& Simpson, 1999; Maurer, Weiss, \& Barbeite, 2003) or seek out training (Colquitt, LePine, \& Noe, 2000; Warr \& Birdi, 1998). Older workers also have fewer developmental opportunities such as challenging job assignments (Maurer, 2007; Wrenn \& Maurer, 2004). Employers are less likely to offer training and developmental to older workers because older workers are perceived to be more expensive and to have a shorter career horizon decreasing the possibility for a return on investment (Simpson, Greller, \& Stroh, 2002; Taylor \& Urwin, 2001). This lack of investment in training is likely to lead to greater skill obsolescence thereby decreasing older workers' employability and making them more susceptible to losing their jobs.

Another career-related stressor that is unique to older employees is retirement. According to Jex and Grosch (in press) as well as Adams and Rau (2011), there is a great deal of variability in the extent to which employees plan for retirement; for some employees the years leading up to retirement may be viewed as quite stressful due to uncertainty about finances, ability to maintain one's health, and how to structure one's time after one is no longer working full-time. Furthermore, the transition into retirement is especially difficult for those who are highly involved in their jobs (Beehr, Glazer, Nielson, \& Farmer, 2000). Fortunately, the weight of the evidence suggests that most people ultimately adjust well to retirement (Beehr \& Adams, 2003; Wang, Henkens, \& Van Solinge, 2011; Wang \& Shultz, 2010).

\section{Age and strain}

As noted earlier, a strain is a negative response that results from exposure to a stressor. Given the wide range of stressors that may be present in the workplace, it should come as no surprise that there are also a vast number of strains. In order to keep this number manageable, occupational stress researchers have typically grouped strains into three relatively exclusive categories: (1) physical, (2) psychological, and (3) behavioral. In the section that follows we review the literature, first regarding the direct relationship between age and strain, and then as a potential moderator of the relationship between stressors and strains.

\section{Physical strains}

Physical strains include reactions to stressors that reflect an employee's physical health and wellbeing. Strains that fall under this category are of considerable importance to both individual employees and also to organizations; in the former case this is due to the potential impact on wellbeing, while in the latter case it is likely due to the impact on health care and related costs (Manning, Jackson, \& Fusilier, 1996). By far the most common method of measuring physical strain has been through the use of self-report physical symptom inventories (e.g., Spector \& Jex, 1998). In some cases, however, researchers 
have utilized more rigorous methods such as physiological measurement (c.g., Schaubroeck, Jones, \& Xie, 2001). With respect to physical strain, it is well established that the human body undergoes a number of physical changes as one ages (Maertens et al., in press). As a result, it should not be surprising that age has a direct relationship with many of the commonly used measures of physical strain. For example, age has been shown to be positively related to number of physical symptoms (Spector \& Jex, 1998), as well as physiological measures such as blood pressure (Fox, Dwyer, \& Ganster, 1993). It has also been shown, as would be expected, that age is positively related to doctor visits and other indicators of healthcare utilization (Ford et al., 2004).

\section{Psychological strains}

Psychological strains typically include emotional/affective reactions to stressors including anxiety, frustration, depression, and anger (Spector \& Jex, 1998). It is worth noting that occupational stress researchers have typically examined what may be described as subclinical levels of the aforementioned affective/emotional states; however, it is certainly possible that stressors in the workplace could contribute to clinically significant anxiety disorders or depressive episodes. The direct relationship between age and psychological strain is somewhat more complex than that for physical strains. For example, it has been shown that the prevalence of clinical depression declines across adulthood (Gatz, 2000). However, it has also been shown that the relation between age and clinical depression may not be linear; specifically, the highest rates appear to be among young adults and those over 75 years of age. Because occupational stress researchers are almost always interested in the assessment of sub-clinical levels of depression, it is unclear whether the existence of age differences in clinically significant depression generalizes to less serious levels. Our own perusal of the occupational literature indicates that age is very weakly related to depression and other negative psychological strains such as anxiety and frustration (Spector \& Jex, 1998), and in fact many studies do not report relations between age and these strains. This suggests age does not have a strong direct relationship with most of the psychological strains measured in the occupational stress literature, and more generally that findings in the clinical literature may not generalize to the measurement of sub-clinical aversive psychological states.

Despite the lack of evidence for a relation between age and psychological strain, there is evidence that age is positively related to positive psychological states such as job satisfaction and organizational commitment $(\mathrm{Ng} \&$ Feldman, 2010; Meyer, Stanley, Herscovitch, $\&$ Topolnytsky, 2002). These positive relations are generally explained in one of two ways. First, as people get older it is more likely they have acquired jobs with characteristics (e.g., higher salary, higher-levels jobs) that lead to satisfaction and commitment. Secondly, increased satisfaction and commitment with age may simply be a way to justify one's long tenure with an organization or the fact that one's job prospects are limited with increasing age. While positive outcomes are not considered to be strains per se (Jex \& Beehr, 1991), they are still important to consider because they are often used as proxy measures of psychological strains in occupational stress rescarch. On a more substantive level, these findings also suggest that as employees get older they may face stressors with a reserve of positive affect.

\section{Behavioral strains}

Behavioral strains represent reactions to stressors that directly or indirectly impact employees' on-the-job behaviors. Perhaps the most common behavioral strain in occupational stress research is job performance, despite the fact that research investigating the relationship between stressors and performance has been quite mixed (Jex, 1998). In addition to performance, other common behavioral strains examined in occupational stress research include turnover intentions (Jamal, 1990), accidents (Greiner, Kraus, 
Ragland, \& Fischer, 1998), and counterproductive work behaviors (Spector \& Fox, 2005 ). When we consider the direct relationship between age and behavioral strains, empirical evidence is again quite mixed. For example, while there is considerable evidence for the existence of age-related declines in job-related tasks that require speed of processing (Salthouse, 1996) and physical exertion (Seitsamo \& Martikainen, 1999), the evidence regarding other types of job tasks is less clear. Thus, it is difficult to make a general statement of whether age has a detrimental effect on performance. If one looks at other types of potential behavioral reactions to stressors, such as accidents and counterproductive behaviors, there is evidence that age is negatively related ( $\mathrm{Ng} \&$ Feldman, 2008; Ng \& Feldman, 2010; Sprung, 2011).

\section{Age as a moderator between stressors and strain}

As stated earlier, if age is viewed as a moderator variable this means that the strength of the relationship between stressors and strains differs at different age levels. As with the evidence for a direct relationship, the evidence for age as a moderator variable is quite mixed. For example, utilizing a sample of firefighters, electricians, and managers, Mayes, Barton, and Ganster (1991) found that role conflict and underutilization of skills had a stronger negative effect, both in terms of psychological and physical strain, on older employees. Conversely, in this same sample it was found older employees responded positively, in terms of all outcomes, to responsibility for others, role ambiguity, and leader production emphasis. These findings suggest that balancing multiple role demands may be more difficult for older employees, perhaps due to cognitive changes associated with increased age. It may also be the case when older employees feel underutilized this is particularly stressful since their future job prospects may be less certain than their younger colleagues. The other findings from the Mayes et al. (1991) study, however, suggests that increased age can be a resource in helping employees cope with certain types of stressors. As Jex, Wang, and Zarubin (2007) point out, older employees have more varied job experiences and therefore may have acquired more effective coping responses when faced with some stressors.

In addition to directly moderating stressorstrain relationships, it is also possible that age may serve as a higher-order moderator in the stress process. Recently, Shultz, Wang, Crimmins, and Fischer (2010) examined whether age moderated the interaction between job demands and job control which is proposed by the well-known Demands-Control model of stress (Karasek, 1979). These researchers found only one demand-control interaction among younger employees; specifically having more time to complete tasks buffered the impact of problem solving demands. For older employees, however, they found three demand-control interactions. Specifically, having both sufficient time and job autonomy both buffered the impact of time deadlines; in addition, scheduling flexibility buffered the impact of problems solving demands. The overall implication of this study is that age may impact how employees use job-related control, and which types of control are the most important. Since this study was done very recently there have not as yet been any replications, however, this would certainly be a fruitful topic for future research in the moderating effects of age.

Overall, it appears that age does have a direct relationship with a number of stressors and strain outcomes. What is less clear and consistent, however, is the strength and direction of these effects. Age also appears to act as a moderator and a higher order moderator of the relationship between stressors and strains. Thus, researchers would be well advised to study it more closely or at least use age as a control variable.

\section{AGE AND SAFETY}

Research in the area of workplace safety grew out of the health- and engineering-related 
fields where there is a long tradition of attempting to identify and mitigate physical hazards in the workplace. Much of this work has focused on physical controls (e.g., hearing protection, machine guarding, ergonomic design, etc.) to reduce or eliminate accidents and injuries. These are beyond the scope of our review. Rather, we focus our attention on the growing stream of research that examines the role of employee attitudes and behaviors as antecedents to accidents and injuries.

\section{Safety attitudes}

An attitude is an evaluation of a person, entity or idea that has some impact on behavior (Eagly \& Chaiken, 1993). It is important to study attitudes in relation to occupational safety because it has long been recognized that attitudes are linked to behavior (Kim \& Hunter, 1993), and existing models of occupational safety include attitudes as distal predictors of accidents and injuries (Christian, Bradley, Wallace \& Burke, 2009). In a safety context, one would anticipate if someone had a more positive attitude toward occupational safety he/she would be more apt to engage in positive safety performance which hopefully would lead to fewer accidents and injuries (Christian et al., 2009).

There are a number of theories which help to explain why age might be related to job attitudes, including attitudes toward safety. One such theory is socioemotional selectivity theory (Carstensen, 1991). As noted earlier, this theory suggests that people consciously and subconsciously monitor the amount of time they have left in the world, and try to maximize their social and emotional gains and minimize their losses. Therefore, older adults want to and do have more positive emotional experiences than negative emotional experiences (Gross, Carstensen, Tsai, Skorpen, \& Hsu, 1997). Older workers experience more positive emotional states, and they are expected to have more positive attitudes in general. When one investigates the research literature on age and job attitudes, one finds support for this idea. Indeed, a recent comprehensive meta-analysis of age and job attitudes found that in general older people tend to have more positive job attitudes than younger people ( $\mathrm{Ng} \&$ Feldman, 2010).

There is little research on age and safety attitudes; however, the research that does exist seems to suggest that older workers have more positive safety attitudes than younger workers. For instance, Siu, Phillips, and Leung (2003) conducted a study with Chinese construction workers. The results indicated that the older workers had more positive attitudes toward safety. Similarly, Gyekye, and Salminen (2009) and Parkes (2003) found that older workers had more positive perceptions of safety than younger workers in samples of Ghanaian industrial workers and people working on oil and gas installations in the North Sea. This general finding was further supported by Grosch and Pransky (2009) in a qualitative review which noted that older workers have significantly higher pre-injury job satisfaction, are more satisfied with the response of their employers, and report fewer problems returning to work. This research is consistent with the idea that age has a positive direct relationship with safety attitudes.

\section{Safety performance}

Safety performance is a term that has been used to reference both safety-related behavior at work and safety-related outcomes such as accidents and injuries. For our purposes, safety performance refers to job-related behavior that promotes the health and safety of workers, clients, the public, and the environment (Burke, Sapry, Tesluk, \& SmithCrowe, 2002; Christian et al., 2009; Griffin \& Neal 2000; Hofmann, Morgeson, \& Gerras, 2003). Safety performance has been conceptualized as a multi-dimensional construct, and Griffin and Neal (2000) differentiated between safety compliance and safety participation. Safety compliance refers to core safety activities that need to be carried out by individuals to maintain workplace safety (e.g., following safety policies and procedures). Safety participation refers to behavior 
which indirectly contributes to workplace safety by helping to develop an environment that promotes safety (e.g. attending voluntary safety meetings and training). We focus on safety performance because there seems to be a clear relationship between safety performance and accidents and injuries (Christian et al., 2009).

Like many of the other antecedents in Figure 15.1 , there are two competing arguments for the relationship between age and safety performance. One argument is that agerelated losses of physical (Macrtens et al., in press) and fluid cognitive abilities (Park, 2000) will lead to poor job performance among older workers, including poor safety performance. The second is that older workers are able to adapt to these losses by using the selection, optimization, and compensation strategies (Freund \& Baltes, 2002) described earlier and by leveraging gains in crystallized intelligence (i.e., accumulated knowledge or wisdom) (Kanfer \& Ackerman, 2004). SOC theory suggests that older people aiming at successful job performance are going to compensate for age-related declines by allocating more resources to maintenance and regulation of loss activities than growth activities. If this is true, older people may have better safety performance than younger people.

Similar to safety attitudes little empirical research has explored the relationship between age and safety performance. This is clearly seen in a recent meta-analysis of the relationship between age and job performance (Ng \& Feldman, 2008). These authors included safety performance; however they only found five studies to analyze. These all focused on safety compliance. That metaanalysis found the sample-size weighted corrected correlation was $r=.10$. This is not terribly different than what has been found when investigating the relationship between age and job performance in general. Both $\mathrm{Ng}$ and Feldman's (2008) quantitative review and Warr's (1994) qualitative review result in similar conclusions: there seems to be a small direct relationship between age and performance.

\section{Occupational accidents and injuries}

As compared to safety attitudes and performance, there is substantially more research which has explored relationships between age and accidents and injuries. Generally, older workers are thought to have lower accident rates than younger workers (Crawford, Graveling, Cowic, Dixon, \& MacCalman, 2010; Jex et al., 2007). There has been some variability in empirical findings. For instance, Siu et al. (2003) found that age was not related to accident rates. Gyekye and Salminen (2009) found that older workers had the lowest accident involvement rate. However, it has been suggested that these inconsistencies could be due to differences in industries and age cohorts. Butani (1988) has also suggested that accident frequency actually varies more by experience than age.

With regard to injuries, research clearly indicates that the findings vary depending on whether the injuries are non-fatal or fatal. A majority of studies show that older workers have fewer non-fatal injuries than younger workers (Hansson, DeKoekkoek, Neece, \& Patterson, 1997; Ng \& Feldman, 2008). A recent qualitative review suggests that this relationship is curvilinear (Grosch \& Pransky, 2009). Grosch and Pransky (2009) cite statistics from the United States Bureau of Labor Statistics which indicate that the rate of non-fatal injuries/illnesses gradually declines with age until it levels off for workers 65 years and older.

Grosch and Pransky (2009) suggested a number of reasons that older workers may experience fewer non-fatal injuries and illnesses than older workers. These authors suggested that older workers may actually be in positions which call for less exposure to hazards due to seniority and having greater control over their work. These findings also might be the result of age often being related to experience. It may be that significant experience and knowledge helps older workers avoid these injuries (Butani, 1988). Finally, Grosch and Pransky (2009) also suggest that the difference between the injury rates 
of younger and older workers might be driven by the 'healthy worker selection effect'. In other words, workers who are more prone to injuries may no longer be employed or at the very least workers who are more prone to injuries in specific jobs may have opted to pursue less hazardous work. These assertions seem consistent with what SOC theory would suggest. Older workers may be compensating for age-related declines in abilities by focusing on different outcomes (i.c., selecting different jobs) or by allocating more resources to maintenance and regulation of loss activities such as safety performance which could lead to fewer injuries.

Empirical findings exploring the relationship between age and fatal injuries are substantially different than those for non-fatal injuries. A majority of studies find that younger workers have less fatal injuries than older workers. In fact the fatality rate for those over 65 in the US is three times that of younger workers (Crawford et al., 2010). Similarly, Grosch and Pransky (2009) noted that there seems to be a dramatic increase in fatal injuries for workers 65 and older. These findings are consistent with those exploring the connection between age and injury severity. This research seems to suggest that older workers sustain more severe injuries and miss more work due to injuries (Crawford et al., 2010; Grosch \& Pransky, 2009; Hansson et al., 1997; Liao, Arvey, Butler, \& Nutting, 2001).

The age-related differences in fatal occupational injuries and injury severity have been explained in a number of ways. Some have suggested that older workers are more susceptible to more severe and fatal injuries due to lower baseline functioning (Brorsson, 1989; Grosch \& Pransky, 2009). There is significant research indicating that there are age-related declines in reaction time, vision, aerobic capacity, muscular strength, and endurance to name a few (Crawford et al., 2010). Research has also suggested agerelated declines in hardiness and recovery speed (Butler, Hartwig, \& Gardner, 1997). All of these could be connected to increases in fatal injuries. Grosch and Pransky (2009) suggest that these differences could also be due to age-related differences in the cumulative effect of repeated exposures to hazards. For instance, employees may engage in improper lifting practices throughout their employment yet not see the effects of doing so until later in life. Further, employees may be able to cut corners and recover when younger but be less capable of doing so later in life (e.g., falling and catching themselves). These explanations are consistent with the idea that age acts as a moderator, in this case a vulnerability factor, in the relationship between working conditions and safety outcomes.

In summary, it appears that age does have a direct positive relationship with safety attitudes and performance but its relationship to outcomes depends on the type of accident or injury. Older workers have fewer accidents and non-fatal injuries but more severe and fatal injuries. Thus, researchers would be well advised to study it more closely or at least use age as a control variable.

\section{FUTURE RESEARCH DIRECTIONS}

In reviewing this literature it becomes clear that there are significant gaps in our understanding of the connection between age and occupational stress and safety. We believe three needs stand out above some others. Perhaps the most pressing needs are the theoretical development and empirical research aimed at reconciling the competing predictions of the loss-based and gain-based views for the role of age in the occupational stress and safety processes.

One way to begin would be for researchers to consider alternative measures of age rather than focusing solely on chronological age. Some other measures of age in the workplace that would seem especially relevant include functional age and social age (Sterns \& Doverspike, 1989; Cleveland \& Lim, 2007). Functional age measures are intended to capture a person's standing on age-related changes in physical and cognitive ability, 
which may more clearly address the losses and gains than chronological age (e.g., the work ability index, Toumi, Ilmarinen, Katajajarinne, \& Tuki, 1998). Social age measures are intended to capture how one's age is perceived by others. These measures would seem relevant for studying stressors arising from ageism. Another approach would be to examine the conditions under which losses and gains are more (or less) likely to impact occupational stress and safety. As a starting point this research could begin by adapting Warr's (1994) model relating age to job performance to the study of occupational stress and safety (Laflamme \& Menckel, 1995). In this model predictions about the impact of gains and losses associated with aging depend on the type of task performed on the job. It would seem that this model is readily adaptable to the study of the types of antecedents and outcomes found in the occupational stress and safety literatures. It also scems that because jobs are embedded in organizations which are then embedded in industries more multi-level research should be conducted.

A second area for future research would be to examine the joint effects of age and factors that co-vary with other demographic characteristics such as gender and ethnicity. The workforce is not only growing older but more diverse and mounting evidence suggests that occupational stress and safety can vary depending on these other characteristics. For example, with regard to gender, there is evidence that the difference in non-fatal injuries between young and old men is greater than the difference between young and old women. There is data from the United Kingdom which reveals that older males (over 55) had the lowest rate of reportable non-fatal injuries where females had the highest rate (Crawford et al., 2010). Some have suggested that these differences might be due in part to women's greater vulnerability to arthritis and other autoimmune diseases and osteoporosis and also the negative effects of stress on menopausal and postmenopausal health (Granville \& Evandrou, 2010; Payne \& Doyal, 2010).
Some have also suggested that this might be the result of women and men doing different work. It has been noted that women are more often in lower paid, lower status jobs, more likely to engage in part-time work, and may do more unpaid work at home than men (Granville \& Evandrou, 2010; Payne \& Doyal, 2010).

A third area where there is a pressing need is intervention research (Crawford et al., 2010; Grosch \& Pransky, 2009). The existing research on age and occupational stress and safety in general is somewhat limited. However, research which explores how the effectiveness of interventions might vary in relation to age is extremely limited. Grosch and Pransky (2009) noted that few public policy strategies aimed at encouraging people to remain in the workforce longer actually are evaluated in terms of what this policy would do to worker safety. This is viewed as a significant limitation, and one that research should not ignore. It seems that age-related physical and mental declines could negatively impact occupational stress and safety outcomes, however, empirical evidence seems to suggest that there are positive relationships between age and stressors, safety attitudes and performance in addition to negative relationships between age and at least some outcomes (i.e., non-fatal injuries). This suggests that older workers are compensating in some way for negative changes in ability and that many of them are being successful in doing so. This may offer insight in how to create more effective safety interventions.

\section{CONCLUSION}

This review demonstrates that age plays an important role in the occupational stress and safety process. It may have a direct positive or negative relationship to specific antecedents and outcomes and it may influence the relationship between those antecedents and outcomes. It is also clear that age reflects more than simply a number of years. However, given the competing predictions as well 
as the scant and often conflicting empirical results found in the literature, it is clear that there is much more work to be done. A better understanding of the role of age in the occupational stress and safety process is imperative to achieving a healthy workplace not just for older workers, but ultimately for all workers.

\section{REFERENCES}

Ackerman, P.L., Beier, M.E., \& Bowen, K.R. (2002). What we really know about our abilities and our knowledge. Personality and Individual Differences, 33, 587-605.

Adams, G.A., \& Rau, B.L. (2011). Putting off tomorrow to do what you want today: Planning for retirement. American Psychologist, 66, 180-192.

Andersson, L.M., \& Pearson, C.M. (1999). Tit for tat? The spiraling effect of incivility in the workplace. The Academy of Management Review, 24, 452-471.

Armstrong-Stassen, M. \& Cattaneo, J. (2010). The effect of downsizing on organizational practices targeting older workers. Journal of Management Development, 29, 344-363.

Baltes, P.B. (1997). On the incomplete architecture of human ontogeny: Selection, optimization, and compensation as foundation of developmental theory. American Psychologist, 52, 366-380.

Baltes, P.B., \& Baites, M.M. (1990). Psychological perspectives on successful aging: The model of selective optimization with compensation. In P.B. Baltes \& M.M. Baltes (Eds.), Successful aging: Perspectives from the behavioral sciences (pp. 1-34). New York: Cambridge University Press.

Barlow, L., \& Iverson, R.D. (2004). Workplace safety. In J. Barling, E.K. Kelloway, \& M.R. Frone (Eds.), Handbook of work stress (pp. 247-266). Portland, OR: Book News, Inc.

Beehr, T.A., \& Adams, G.A. (2003). Introduction and overview of current research and thinking on retirement. In G.A. Adams \& T.A. Beehr (Eds.), Retirement: Reasons, processes, and results (pp. 1-15). New York: Springer Publishing Company.

Beehr, T.A., Glazer, S., Nielson, N.L., \& Farmer, S.J. (2000). Work and non-work predictors ot employees' retirement ages. Journal of Vocational Behavior, 57 , 206-225.

Birditt, K.S., \& Fingerman, K.L. (2003). Age and gender differences in adults' descriptions of emotional reactions to interpersonal problems. Journal of
Gerontology: Series B: Psychological Sciences and Social Sciences, 58, 121-128.

Birditt, K.S., \& Fingerman, K.L. (2005). Do we get better at picking our battles? Age differences in descriptions of behavioral reactions to interpersonal tensions. Journals of Gerontology, Psychological Sciences and Social Sciences, 60, 121-128.

Brooke, L., \& Taylor, P. (2005). Older workers and employment: Managing age relations. Ageing \& Society, 25, 415-249.

Brorsson, B. (1989). The risk of accidents among older drivers. Scandinavian Journal of Public Health, 17 . 253-256.

Burke, M.J., Sapry, S.A, Tesluk, P.E., \& Smith-Crowe, K. (2002). General safety performance: A test of a grounded theoretical model. Personnel Psychology, $55,429-457$.

Burke, R., \& Ng, E. (2006). The changing nature of work and organizations: Implications for human resource management. Human Resource Management Review, 16, 86-94.

Butani, S.J. (1988). Relative risk analysis of injuries in coal mining by age and experience at present company Journal of Occupational Accidents, 10, 209-216.

Butler, R. (1989). Dispelling ageism: The cross-cutting intervention. Annuals of the American Academy of Political and Social Science, 503, 138-147

Butler, R.J., Hartwig, R.P., \& Gardner, H.H. (1997). HMO's, moral hazard, and cost shifting in workers' compensation. Journal of Health Economics, 16, 191-206.

Carstensen, L.L. (1991). Selectivity theory: Social activity in life-span context. Annual Review of Gerontology and Geriatrics, 11, 195-217

Carstensen, L.L., Isaacowitz, D., \& Charles, S.T. (1999). Taking time seriously: A theory of socioemotional selectivity. American Psychologist, 54, 165-181.

Centers for Disease Control and Prevention (2011). Nonfatal Occupational injuries and illnesses among older workers: United States 2009. Retrieved 12/28/2011 from: http://www.cdc.gov/mmwr/ preview/mmwrhtml/mm6016a3.htm

Charness, N., Czaja, S., \& Sharit, J. (2007). Age and technology for work. In K.S. Shultz, G.A. Adams, K.S. Shultz, G.A. Adams (Eds.). Aging and work in the 21st century (pp. 225-249). Mahwah, NJ US: Lawrence Erlbaum Associates Publishers.

Christian, M., Bradley, J., Wallace, C., Burke, M. (2009). Workplace Safety: A Meta-Analysis of the Roles of Person and Situation Factors. Journal of Applied Psychology, 94, 1103-1127.

Cleveland, J.N., \& Lim, A.S. (2007). Employee age and performance in organizations, in Shultz, K.S. and 
G.A. Adams (Eds), Aging and Work in the 21st Century, Lawrence Erlbaum Associates, Mahwah, NJ, pp. 109-38.

Colquitt, J.A., LePine, J.A., \& Noe, R. (2000). Toward an integrative theory of training motivation: A metaanalytic path analysis of 20 years of research. Journal of Applied Psychology, 85, 678-707.

Crawford, J.O., Graveling, R.A., Cowie, H., Dixon, K., \& MacCalman, L. (2010). The health, safety and health promotion for older workers. Occupational Medicine, 60, 184-192.

Dahling, J.J., \& Perez, L.A. (2010). Older worker, different actor? Linking age and emotional labor strategies. Personality And Individual Differences, 48(5), 574-578.

DeLong, D. (2004). Lost knowledge: Confronting the threat of an aging workforce. New York: Oxford University Press.

Dendinger, V., Adams, G., \& Jacobson, J. (2005). Reasons for working and their relationship to retirement attitudes, job satisfaction and occupational self-efficacy of bridge employees. International Journal of Aging \& Human Development, 61, 21-35.

Eagly, A.H., \& Chaiken, S. (1993). The Psychology of Attitudes, Orlando, FL US: Harcourt Brace Jovanovich College Publishers.

The Economist (2011). Special report: Pensions falling short. London, UK: The Economist Newspaper Limited.

Equal Employment Opportunity Commission (2011). Age Discrimination in Employment Act (includes concurrent charges with Title VII, ADA and EPA) FY 1997-FY 2010. Washington, DC: Author. Available at: Wuw. eeoc.gov/eeoc/statistics/enforcement.adea.cfm

European Agency for Safety and Health at Work. (2009). Outlook 1: New and emerging risks in occupational safety and health. Luxembourg: Office of Official Publications of the European Communities.

Finkelstein, L.M., \& Farrell, S.K. (2007). An expanded view of age bias in the workplace. In K. Shultz and G. Adams (Eds.), Aging and Work in the 21st Century (pp. 73-108). Hillsdale, NJ: Lawrence Eribaum.

Fiske, S.T., \& Neuberg, S.L. (1990). A continuum of impression formation, from category-based to individuating processes: Influences of information and motivation on attention and interpretation. In M.P. Zanna (Ed.), Advances in experimental social psychology (Vol. 23, pp. 1-74). New York: Academic Press.

Ford, J.D., Schnurr, P.P., Friedman, M.J., Green, B.L., Adams, G.A., \& Jex, S.M. (2004). Posttraumatic stress disorder symptoms, physicai health, and health care utilization fifty years after repeated exposure to a toxic gas. Journal of Traumatic Stress, 17, 185-194.

Fox, M.L., Dwyer, D.J., \& Ganster, D.C. (1993). Effects of stressful job demands and control on physiological and attitudinal outcomes in a hospital setting. Academy of Management Journal, 36, 289-318.

Freund, A.M., \& Baltes, P.B. (2002). Life-management strategies of selection, optimization, and compensation: Measurement by self-report and construct validity. Journal of Personality \& Social Psychology, 82, 642-662

Gatz, M. (2000). Variations on depression in later life. In S.H. Qualls \& N. Ables (Eds.), Psychology and the aging revolution: How we adapt to longer life (pp. 239-254). Washington, DC: American Psychological Association.

Giniger, S., Dispenzieri, A., \& Eisenberg, J. (1983). Age, experience and performance on speed and skill jobs in an applied setting. Journal of Applied Psychology, 68, 469-475.

Gordon, R.A. \& Arvey, R.D. (2004). Age bias in laboratory and field settings: A meta-analytic investigation. Journal of Applied Social Psychology, 34, 1-27.

Granville, G., \& Evandrou, M. (2010) Older men, work and health. Occupationa/ Medicine, 60, 178-183.

Greiner, B.A., Kraus, N., Ragland, D.R., \& Fisher, J.M. (1998). Objective stress factors, accidents, and absenteeism in transit operators: A theoretical framework and empirical evidence. Journal of Occupational Health Psychology, 3, 130-146.

Greller, M.M., \& Simpson, P.A. (1999). In search of late career: A review of contemporary social science research applicable to the understanding of late career. Human Resource Management Review, 9, 309-347.

Griffin, M.A., \& Neal, A. (2000). Perceptions of safety at work: A framework for linking safety climate to safety performance, knowledge, and motivation. Journal of Occupational Health Psychology, 5, 347-358.

Grosch, J.W., \& Pransky, G.S. (2009). Safety and health issues for an aging workforce. In S.J. Czaja, J. Sharit, \& J. Sharit (Eds.), Aging and work: Issues and implications in a changing landscape (pp. 334-358). Baltimore, MD US: Johns Hopkins University Press.

Gross J.J., Carstensen L.L., Tsai J., Skorpen C.G., \& Hsu A.Y.C. (1997). Emotion and aging: Experience, expression, and control. Psychology and Aging, 12, 590-599.

Gyekye, S.A., \& Salminen (2009). Age and workers' perceptions of workplace safety: A comparative study. International Journal of Aging and Human Development, 68, 171-184. 
Hansson, R.O., DeKoekkoek, P.D., Neece, W.M., \& Patterson, D.W. (1997). Successful aging at work: Annual review, 1992-1996: The older worker and transitions to retirement Journal of Vocational Behavior, 51, 202-233.

Hershcovis, M.S. (2011). Incivility, social undermining, bullying ... oh my!: A call to reconcile constructs within workplace aggression research. Journal of Organizational Behavior, 32, 499-519.

Hofmann, D.A., Morgeson, F.P., \& Gerras, S.J. (2003). Climate as a moderator of the relationship between leader-member exchange and content specific citizenship: Safety climate as an exemplar. Journal of Applied Psychology, 88, 170-178

International Labour Organization. (2011). NO introductory report: Global trends and challenges in occupational safety and health. XIX World Congress on Safety and Health at Work. International Labour Office. Geneva, ll.o.

Jackson, S.E., \& Schuler, R.S. (1985). A meta-analysis and conceptual critique of research on role ambiguity and role conflict in work settings. Organizational Behavior and Human Decision Processes, 36, 16-78.

Jamal, M. (1990). Relationship of Type-A behavior to employees' job satisfaction, organizational commitment, psychosomatic health problems, and turnover motivation. Human Relations, 43, 727-738.

Jex, S.M. (1998). Stress and job performance: Theory, research, and Implications for managerial practice. Thousand Oaks, CA: Sage.

Jex, S.M., \& Beehr, T.A. (1991). Emerging theoretical and methodological issues in the study of workrelated stress. In K. Rowland \& G. Ferris (Eds.), Research in Personnel and Human Resources Management (Vol. 9, pp. 311-365). Greenwich, CT: JAl Press.

Jex, S.M., \& Crossley, C.D. (2005). Organizational consequences. In J. Barling, E.K. Kelloway \& M. Frone (Eds.), Handbook of work stress (pp. 5-599). Thousand Oaks: Sage Publications.

Jex, S.M., \& Grosch, J. (in press). Retirement decision making. in M. Wang (Ed.), The Oxford Handbook of Retirement.

Jex, S.M., Wang, M., \& Zarubin, A. (2007). Aging and occupational health. In K.S. Shultz \& G.A. Adams (Eds.), Aging and work in the 21st century: Applied psychology series (pp. 199-223). Mahwah, NJ, US: Lawrence Erlbaum Associates Publishers.

Kahn, R.L., \& Byosiere, P. (1992). Stress in organizations. In M.D. Dunnette \& L.M. Hough (Eds.), Handbook of industrial and organizational psychology (2nd ed., Vol. 2, pp. 571-650). Palo Alto, CA: Consulting Psychologists Press.
Kanfer, R., \& Ackerman, P.L. (2004). Aging, adult development and work motivation. Academy of Management Review, 29(3), 440-458. doi:10.5465/ AMR.2004.13670969

Karasek, R.A. (1979). Job demands, job decision latitude, and mental strain: Implications for job re-design. Administrative Science Quarterly, 24, 285-306.

Katz, D., \& Kahn, R.L. (1978). The social psychology of organizations (2nd ed.). New York: Wiley.

Kaufman, A.S., \& Lichtenberger, E.O. (2002). Assessing adolescent and adult intelligence (2nd ed.). Boston: Allyn \& Bacon.

Kim, M. \& Hunter, J. (1993). Attitude-behavior relations: A meta-analysis of attitudinal relevance and topic. Journal of Communication, 43, 101-142.

Kinsella, K., \& He, W. (2009). An aging world: 2008. US Census Bureau, International Population Reports. Washington, DC: US Government Printing Office.

Kite, M.E., \& Johnson, B.T. (1988). Attitudes toward older and younger adults: A meta-analysis. Psychology and Aging, 3, 233-244.

Laflamme, L., \& Menckel, E. (1995). Aging and occupational accidents: A review of the literature of the last three decades. Safety Science, 21, 145-161.

Leka, S., \& Jain, A. (2010). Health impact of psychosocial hazards at work: An overview. World Health Organization. University of Nottingham.

Liao, H., Arvey, R.D., Butler, R.J., \& Nutting, S.M. (2001). Correlates of work injury frequency and duration among firefighters. Journal of Occupational Health Psychology, 6, 229-242.

Loi, J., \& Shultz, K. (2007). Why older adults seek employment: Differing motivations among subgroups. Journal of Applied Gerontology, 26, 274-289.

Maertens, J., Putter, S., Chen, P.Y., Manfred, D., Huang, Y.H. (in press). Physical capabilities and occupational health of older workers. In J.W. Hedge and W. C. Borman (Eds), Oxford handbook of work and aging. New York, NY: Oxford University Press.

Manning, M.R., Jackson, C.N., \& Fusilier, M.R. (1996). Occupational stress, social support, and the costs of health care. Academy of Management Journal, 39, 738-750.

Manpower Group (2011). Talent shortage survey results. Milwaukee, WI: Manpower Group. Retrieved from: http://us.manpower.com/us/en/multimedia/ 2011-Talent-Shortage-Survey.pdf

Mather, M., \& Carstensen, L.L. (2005). Aging and motivated cognition: The positivity effect in attention and memory. Trends in Cognitive Science, 9, 496-502.

Maurer, T. (2007). Employee development and training issues related to the aging workforce. In K. Shultz \& 
G. Adams (Eds.) Aging and work in the 21st century. New Jersey: Lawrence Erlbaum Associates.

Maurer, T., Weiss, E., \& Barbeite, F. (2003). A model of involvement in work-related learning and development activity: The effects of individual, situational, motivational, and age variables. Journal of Applied Psychology, 88, 707-724

Mayes, B.T, Barton, M.E., \& Ganster, D.T. (1991). An exploration of the moderating effect of age on stressor-employee strain relationships. Journal of Social Behavior and Personality, 6, 389-398.

Meyer, J.P., Stanley, D.J., Herscovitch, L., \& Topolnytsky, L. (2002). Affective, continuance, and normative commitment to the organization: A meta-analysis of antecedents, correlates, and consequences. Journal of Vocational Behavior, 61, 20-52

$\mathrm{Ng}$, T.H., \& Feldman, D.C. (2008). The relationship of age to ten dimensions of job performance. Journal of Applied Psychology, 93(2), 392-423.

$\mathrm{Ng}$, T.W.H., \& Feldman, D.C. (2010). The relationships of age with job attitudes: A meta-analysis. Personnel Psychology, 63, 677-718.

Park, D.C. (2000). The basic mechanisms accounting for age-related decline in cognitive function. In D.C. Park and N. Schwarz (Eds.), Cognitive aging: $A$ primer (pp. 3-21). Philadelphia PA: Psychology Press.

Parkes, K.R. (2003). Shiftwork and environment as interactive predictors of work perceptions. Journal of Occupational Health Psychology, 8, 266-281.

Payne, S., \& Doyal, L. (2010). Older women, work and health. Occupational Medicine, 60(3), 172.

Probst, T.M. (2004). Job insecurity: Exploring a new threat to employee safety. In J. Barling, M.R. Frone, J. Barling, M.R. Frone (Eds.), The psychology of workplace safety (pp. 63-80). Washington, DC: American Psychological Association.

Rayner, C. (1997). The incidence of workplace bullying. Journal of Community \& Applied Social Psychology, 7. 199-208.

Ready, R.E., \& Robinson, M.D. (2008). Do older individuals adapt to their traits?: Personality-emotion relations among younger and older adults. Journal of Research in Personality, 42, 1020-1030.

Rupp, D.E., Vodanovich, S.J., \& Crede, M. (2006). Age bias in the workplace: The impact of ageism and causal attributions. Journal of Applied Social Psychology, 36, 1337-1364.

Salthouse, T.A. (1996). The processing-speed theory of adult age differences in cognition. Psychological Review, 103, 403-428.

Salthouse, T.A., \& Maurer, T.J. (1996). Aging, job performance, and career development. In J.E. Birren, K. Schaie, R.P. Abeles, M. Gatz, T.A. Salthouse, J.E.
Birren, T.A. Salthouse (Eds.), Handbook of the psychology of aging (4th ed.) (pp. 353-364). San Diego, CA US: Academic Press.

Schaie, K.W. (1996). Intellectual development in adulthood. In J.E. Birren \& K.W. Schaie (Eds.), Handbook of the psychology of aging (4th ed.) (pp. 266-286). San Diego: Academic Press.

Schaubroeck, J., Jones, J.R., \& Xie, J.L. (2001). Individual differences in utilizing control to cope with job demands: Effects on susceptibility to infectious disease. Journal of Applied Psychology, 86, 265-278.

Shultz, K.S., Wang, M., Crimmins, E., \& Fisher, G.F. (2010). Age differences in the Demand-Control Model of work stress: An examination of data from 15 European countries. Journal of Applied Gerontology, 29, 21-47.

Seitsamo, J., \& Martikainen, R. (1999). Changes in capability in a sample of Finnish aging workers. Experimental Aging Research, 1, 345-352.

Shore, L.M., \& Goldberg, C.B. (2004). Age discrimination in the workplace. In R.L. Dipboye \& A. Colella (Eds.), Discrimination at work: The psychological and organizational bases (pp. 203-222). London: Lawrence Erlbaum Associates.

Simpson, P.A., Greller, M.M., \& Stroh, L.K. (2002). Variation in human capital investment activity by age. Journal of Vocational Behavior, 61, 109-138.

Siu, O., Phillips, D.R., \& Leung, T. (2003). Age differences in safety attitudes and safety performance in Hong Kong construction workers. Journal of Safety Research, 34, 199-205.

Sonnentag, S., \& Frese, M. (2003). Stress in organizations. In W.C. Borman, D.R. \|gen, \& R.J. Klimoski (Eds.), Comprehensive handbook of psychology: Industrial and organizational psychology (Vol 12., pp. 453-491). New York: Wiley.

Spector, P.E., \& Fox, S. (2005). A model of counterproductive work behavior. In S. Fox \& Spector, P.E. (Eds.), Counterproductive workplace behavior: Investigations of actors and targets (pp. 151-174). Washington, DC: American Psychological Association. Spector, P.E., \& Jex, S.M. (1998). Development of four self-report measures of job stressors and strain: Interpersonal Conflict at Work Scale, Organizational Constraints Scale, Quantitative Workload Inventory, and Physical Symptoms Inventory. Journal of Occupational Health Psychology, 3, 356-367.

Sprung, J. (2011). Work locus of control as a moderator of the relationship between work stressors and counterproductive work behavior. Unpublished master's thesis, Bowling Green State University, Bowling Green, $\mathrm{OH}$.

Sterns, H.L., \& Doverspike, D. (1989). Aging and the retraining and learning process in organizations. 
In I. Goldstein \& R. Katzel (Eds.), Training and development in work organizations (pp. 229-332). San Francisco, CA: Jossey-Bass.

Taylor, P., \& Umwin, P. (2001). Age and participation in vocational education and training. Work, Employment \& Society, 15, 763-779.

Tepper, B.J. (2000). Consequences of abusive supervision. Academy of Management Journal, 43, 178-190.

Wang, M., \& Chen, Y. (2006). Age differences in attitude change: Influences of cognitive resources and motivation on responses to argument quantity. Psychology and Aging, 21, 581-589.

Wang, M., \& Shultz, K.S. (2010). Employee retirement: A review and recommendations for future investigation. Journal of Management, 36, 172-206.

Wang, M., Henkens, K., \& van Solinge, H. (2011). Retirement adjustment: A review of theoretical and empirical advancements. American Psychologist. Advance online publication. doi: 10.1037/a0022414.

Warr, P. (1994). Age and employment. In H.C. Triandis, M.D. Dunnette, L.M. Hough (Eds.), Handbook of industrial and organizational psychology (Vol. 4, pp. 485-550). Palo Alto, CA US: Consulting Psychologists Press.

Warr, P. (1997). Age, work, and mental health. In K.W. Schaie \& C. Schooler (Eds.), The Impact of work on older adults (pp. 252-296). New York: Springer.
Warr, P., \& Birdi, K. (1998). Employee age and voluntary development activity. International Journal of Training and Development, 2, 190-204.

Wegman, D.H., \& Mcgee, J.P. (2004). Health and safety needs of older workers. Washington, DC: The National Academic Press.

Wrenn, K.A., \& Maurer, T.J. (2004). Beliefs about older workers' learning and development behavior in relation to beliefs about malleability of skills, agerelated decline, and control. Journal of Applied Social Psychology 34 223-242.

Yeomans, L. (2011). An update of the literature on age and employment. Health and Safety Executive, Buxton, Derbyshire: Harpur Hill.

Yeung, D.Y, \& Fung, H.H. (2009). Aging and work: How do SOC strategies contribute to job performance across adulthood? Psychology and Aging, 24, 927-940.

Zacher, H. \& Frese, M. (2009). Remaining time and opportunities at work: Relationships between age, work characteristics, and occupational future time perspective. Psychology and Aging, 24, 487-493.

Zacher, H., Heusner, S., Schmitz, M., Zwierzanska, M.M., \& Frese, M. (2010). Focus on opportunities as a mediator of the relationships between age, job complexity, and work performance. Journal of Vocational Behavior, 76, 374-386. 